\title{
Local University Research on Local Internationalization
}

\author{
Lipeng Feng and Guoqiang Shi
}

\begin{abstract}
With the development of economic globalization, local universities which the aim is to cultivate application-oriented talents need to adapt to the trend of international development. The local university also need actively develop local internationalization with its own characteristics. The paper reviews the research on university internationalization, localization and local internationalization. To promote local internationalization on local university, the paper summarizes the aim and the way on talents cultivation, talents cultivation programs, teaching methods and language training etc.
\end{abstract}

Index Terms-Local university, local internationalization, talents cultivation.

\section{INTRODUCTION}

Now the international communication in universities becomes more and more. The international cooperation on teaching and academic research has been gradually deepened. There are 2845 universities in China, of which local universities have 2553 . That means nearly $90 \%$ are local universities. The most important goal for university is to cultivate talents for the future. The universities on different levels and types should cultivate different levels talents. The goal for local universities is cultivating applied talents based on the local. These talents will serve the local economic development in future. But with the development of economic globalization, the requirements for high quality talents are increasing. Now the prominent feature of applied talents is with applicable knowledge structure, outstanding ability on occupation group and good international vision [1]. However, due to various reasons, there are big gaps between local universities and key universities on school foundation, education funding, teachers and education concept, etc. Therefore, local universities should have a strong sense of internationalization and the ability to participate in

Manuscript received February 6, 2017; revised April 8, 2017. The paper is financially supported by University research project on Chongqing University of Arts and Science, and 2016 teaching reform project on Chongqing University of Arts and Science.

Lipeng Feng is with the School of Economy and Management, Chongqing University of Arts and Science, Yongchuan Chongqing, China. She is also with School of Economics and Business Administration, Chongqing University, Shapingba, Chongqing, China (e-mail: lpfeng@uow.edu.au).

Guoqiang Shi is with the School of Economy and Management, Chongqing University of Arts and Science, Yongchuan Chongqing, China (e-mail: 332525871@qq.com). international competition.

\section{RELATED RESEARCH}

\section{A. Literature Review on University Internationalization}

Based on the different national environment and the basic conditions of running a school, the research on the internationalization of universities is generally divided into the developed countries and the developing countries. Van M [2] summarized four ways on internationalization of universities in developed countries. First were international exchanges. It mainly included promoting international communication on teachers and students, expanding the quota of foreign students in developing countries, establishing international affairs office and so on. Second was transnational education. The main method was joint cultivating with foreign counterparts and foreign universities. Third was intercollegiate project. It included cooperation on education programs and research projects. Last was the development of overseas courses.

There were five types internationalization on universities in developing countries. First was to promote the reform of University internationalization. It included the internationalization of the school model, resource allocation model and the reform on internal management mechanism. Second was to have international strategy. This can be got by international curriculum, which was similar to the developed countries. Third was actively introducing and learning talents training mode from the world's top university. Forth was the introduction of foreign teachers and advanced teaching methods. Last was to strengthen the foreign language teaching.

Wang [3] argued that the internationalization strategy in Chinese university had four ways: First was to gradually improve internationalization for different region and university. Second was to promote international "development" by "introduction". That meant to promote the internationalization of higher education with the opening of education market. Third was to selectively expand the educational service trade. When taking "bringing in" strategy, we could take more measures on "going out" on education service trade. Last was to join the international competitions ranks by brand.

Furthermore, Ayoubi M [4] and other scholars argued that in order to adapt to the trend of internationalization of higher education, local universities could be targeted to carry out internationalization from the following aspects. First was to choose key areas to carry out international cooperation. Second was to selectively participate in the communication activities organized by government and non government on regional and international. Third was to strengthen 
internationalization infrastructure. Last was to cultivate young teachers.

To sum up, the study on the internationalization strategy on the university was mainly from the perspective of the research results. Most of researchers introduced other country's strategy or related research results. So most of the results were reference to other country experience, and these references would be suggestions on educational institutions and relevant departments of the government.

\section{B. Literature Review on University Localization}

On the localization of university education, experts and scholars described it from the following four aspects.

\section{1) Local creation research}

Wu [5] argued that the establishment of China's education school was a basic path for education localization. Li [6] mentioned: "higher education is not only reading foreign books and foreign materials, but also with scientific methods to study the Chinese situation, in order to find out the proper education method and prompt the education localization of Chinese." Lidström A [7] believed that higher education should have local features based on the local regional economic characteristics, which emphasizes the local education. Therefore, the localization of higher education in China mainly explored two aspects: one was how the new education would adapt to local development; second was to create new education for the needs of social development on the basis of the former.

\section{2) Interaction of multiple factors}

Localization of higher education involves a variety of factors. Only the realization of multiple interactions can really form a localized education. Rumbley E [8] argued that education tradition, education knowledge and knowledge practice were the premise of the elements of education theory localization. Andersson S [9] summarized three ways of localization on higher education: to adjust cultural mentality, to maintain moderate tension in "same" and "difference"; and to find a way between the conflict and fusion.

\section{3) Methodology research on the localization of higher education}

Researchers and scholars put forward the methodology of the research on the localization of higher education. Occhi $\mathbf{J}$ [10] argued there were three qualitative research methods: symbolic interactions, ethonmethodolgy and grounded theory. Gümüşeli $\mathrm{A}[11]$ demonstrated the localization of research strategies.

\section{4) Combination research on Chinese and foreign education}

Ngok [12] summed up the principle on higher education localization and designed corresponding educational administrative system.

In china, marketing competition is inefficient on higher education and the local university has not local advantages. Therefore, we can make full use of foreign high-quality resources and carry out international education in China. To a certain extent, this can make up deficiencies in the process of internationalization of local universities. Many scholars made different researches on local internationalization of universities and draw a lot of useful conclusions. Bo H [13] analyzed the internationalization and localization on legal talents; Sekiwu D [14] studied different cultivating modes on internationalization compound elite talent; Rau P [15] made analysis on student affairs internationalization localization issues; Sekiwu D [14] made a comparison on the internationalization and localization with Uganda; Bunescu I [16]; Willis I [17]; Coró G [18]; Law C [19]; Yassin Z [20]; Dörfer C [21]; Gümüşeli A [22]; YAN X [23] Knight J [24]; ZHANG Y [25] respectively studied local internationalization on different areas, such as knowledge management, technology and finance, curriculum construction, e-government, education, urban and rural areas, education research, personnel training, teacher training and management research, etc.

\section{THE WAY TO WIN LOCAL INTERNATIONALIZATION ON LOCAL UNIVERSITIES}

With the rapid development of the discipline on local universities, the market demand on international and applicable talent is growing and these talents are likely to have more impact on different fields. So there is urgent need for international and applicable talents. Therefore, the local universities could focus on the following aspects to cultivate more talents in the process of internationalization.

\section{A. To Update the Educational Concept and Clarify the Goal of Cultivating Internationalized Talents}

Now to cultivate internationalized talents with intercultural communication competence, high quality, fluent language and excellent professional becomes more and more urgent. To win the goal of cultivating local internationalized talents, local universities should highlight their own characteristics and take the initiative to promote internationalization. Then they need further define the cultivating guidelines by carrying out education and teaching seminar on different levels. What is more important is to actively adapt to the change and development of the talent market, especially to export-oriented enterprises and the "go out" strategy needs.

\section{B. To Improve Cultivating Mode and Explore a Variety of Personnel Training}

To adapt to the trend of internationalization, the local universities have to vigorously carry out the hybrid cultivating mode. The mode can organically integrate multiple talents cultivating modes with a unified cultivating framework besides subject cultivating mode. The subject cultivating mode is for all undergraduate students. Multiple talents cultivating mode refers to selective training mode, which includes the combination of major subject and assistant subject, domestic education and oversea education, academic education and occupation qualification, and professional learning and professional practice, etc.

The mode with the combination of major subject and assistant subject is the training program on which they will obtain a double degree or professional in accordance with the major subject and assistant subject. The mode with domestic education and oversea education is the training program when students complete the course and obtain the corresponding 
credits on domestics, they will continue to study the corresponding professional on foreign university. After they get recognized credits, they can obtain a double degree in domestics and overseas university. "Academic + occupation" model is that when students are studying in university, they study relevant courses on foreign professional education at the same time. Then they will get domestic professional degree and foreign professional certificate. "Professional + practice" mode is that when students study professional knowledge, they participate in relevant professional practice at the same time. So professional learning and professional practice can improve each other.

\section{To Build up Platform and Establish Flexible Talent Cultivation Program}

By public course platform, students are free to choose courses, learning process, lecturers and class time with training scheme. By sharing the discipline basic courses on platform in different faulty, students will have the second chance to choose major. The setup of these two platforms will break disciplinary boundaries and form public basic course platform with various disciplines integration. The two platforms also break college professional boundaries and offer a variety of choices. It really reflects thick foundation and wide caliber talents education attitude. All these will lay the foundation for the students' personality, and it can improve self training and develop the students' employment space at the same time.

\section{To Adopt Multidimensional Teaching Mode}

On the basis of "learning-teaching interaction" multidimensional teaching mode, we can establish a new teaching mode: multidimensional design centered learning (DCL). Furthermore we can construct dimensional curriculum system with "platform + module + Courses" and design hexagonal personalized knowledge structure. It includes basic course, character, organization management, language communication skills, basic knowledge and professional technical knowledge. With the combination of core courses and elective courses, we can establish panorama training model and do panoramic training scheme. We can make improvement on individual development plan, humanistic quality of students and management ability. We should respect individual differences and meet individual needs to achieve the initiative of student learning, the integration of resources and the diversification of teaching and learning. The teaching mode is integrated with multi-discipline, specialization, participation, cooperation and innovation. Besides cultivating students' professional skills, we will also focus on cultivating students' communication ability, cooperation ability and the comprehensive ability of oral expression. The way is benefit for the construction of multicultural. At the same time, it can improve the students' learning ability, innovation ability, practice ability, communication ability and social adaptation ability.

\section{E. To Strengthen English Teaching and Training}

English is the basic tool for international communication and the key to understand foreign cultures. Therefore, to integrate with the international society and keep in touch with the foreign higher education institutions, university should further strengthen English teaching, and then further expand international exchanges between teachers and students.

Now, the way to internationalization of local universities is mainly through international courses and international teaching. Local universities will further spread the "internationalization and borderless" education philosophy, multi-channel practice and stepping progressive innovative education. It will train critical thinking with an open, tolerant, rigorous attitude. On the level of consciousness, we should focus on cultivating students' innovative behavior and pursuing sustainable development.

\section{CONCLUSION}

With economic globalization and internationalization of higher education, local university as a university serving local economic development is an important part of economic globalization. Local universities should timely and accurately grasp the pulse of international economic development and adapt to the needs of national economic development. The local university can implement the local internationalization strategy with highlighting the talent training characteristics of internationalization and application. With innovative talents mode, we can reform the teaching support system, create mutual complementary ways of cultivating talents, make flexible talents cultivation scheme, build major group and course group with international character. The local university must have teachers with international academic background; strengthen management on international academic education project; increase exchanges and integration between international students and local students. The practice of international cultural exchange activities also enable students to construct international knowledge structure, generate high comprehensive quality and international competitive ability with strong and good qualities, and thus form the core in the talent market competitiveness.

\section{ACKNOWLEDGMENT}

The authors thank colleagues from SMART infrastructure facility (the faculty of Engineering and information science, university of Wollongong, Australian) to provide invaluable guidance and contribution of outstanding ideas. The authors would also like to thank the authors of reference.

\section{REFERENCE}

[1] L. M. Zhao, Y. Xu, and H Zhang, "Research and thinking on applied talent training modes," in Proc. International Conference on Management, Information and Educational Engineering, CRC Press, 2015, pp. 893-895.

[2] M.Van, "Internationalization of higher education in the OECD countries: Challenges and opportunities for the coming decade," Journal of Studies in International Education, vol. 11, no. 3-4, pp. 274-289, 2007.

[3] T. Wang, "To develop international characteristic on universities," Research on Higher Engineering Education, vol. 4, pp. 30-35, 2002.

[4] R. M. Ayoubi and H. K. Massoud, "The strategy of internationalization in universities: A quantitative evaluation of the intent and implementation in UK universities," International Journal of educational Management, vol. 21, no. 4, pp. 329-349, 2007. 
[5] L. Wu, "Local consciousness and social responsibility in higher education research," China Higher Education Research, vol. 10, pp. $17-22,2010$

[6] G. Li, "Reflections on the indigenization of higher education internationalization development," Journal of Tianjin Polytechnic University, vol. 6, pp. 10-15, 2002

[7] A. Lidström, Education and Local Development Policies in Sweden, Local Education Policies: Comparing Sweden and Britain, 2016, pp. 123.

[8] L. E Rumbley and P. G. Altbach, The Local and the Global in higher education in internationalization Global and Local Internationalization, Sense Publishers, 2016, pp. 7-13.

[9] S. Andersson and E Berggren, "Born global or local? Factors influencing the internationalization of university spin-offs-the case of Halmstad University," Journal of International Entrepreneurship, vol. 14, no. 3, pp. 296-322, 2016.

[10] D. J. Occhi, "Global and local perspectives on discourses and practices of university internationalization," The Impact of Internationalization on Japanese Higher Education, Sense Publishers, pp. 19-33, 2016.

[11] A. İ Gümüşeli, M.Zagudillin, and Ö. Hacıfazlıŏglu, "Implementation of change at the local level: Motivations for internationalization of higher education among university lecturers," Eğitim ve Bilim Dergisi, 2012.

[12] K. L Ngok and M. H. Lee, "Localization of higher education and its social consequences in China, 1993-2007," Journal of Asian Public Policy, vol. 2, no. 1, pp. 57-73, 2009.

[13] H. Bo, "Study on the internationalization strategy of new founded local universities-based on the practice of Ningbo University," China Higher Education Research, vol. 5, pp. 015, 2014.

[14] D. Sekiwu. (January 2010). From localization to internationalization of higher education: globalization and transformation of university education in Uganda. [Online]. Available: https://eric.ed.gov/?id=ED512372

[15] R. P. Patrick and S. F. M. Liang, "Internationalization and localization: Evaluating and testing a website for Asian users," Ergonomics, vol. 46, no. 1-3, pp. 255-270, 2003.

[16] I. Bunescu, "Local meanings of internationalization of higher education under economic crisis: A critical case study at a Swedish University," presented at the XVIII ISA World Congress of Sociology, Yokohama, Japan, July13-19, 2014.

[17] W. Ian and J. Taylor, "The importance of rationales for internationalization at a local level-university and individual," European Journal of Higher Education, vol. 4, no. 2, pp. 153-166, 2014.
[18] G. Coró and M. Volpe, "Competitiveness, internationalization and local development: Emerging scenarios," Ph.D. dissertation Venice International University, Venice, ITALY, 2010.

[19] L. Jennifer Man Ching, "Internationalization of higher education in Hong Kong-An investigation into the implementation of internationalization strategies for undergraduate programs in a local university," Ph.D. dissertation. University of Bristol, UK. 2012.

[20] S. Z. Yassin, "Designing an international English language programme towards the internationalization of a local public university: The Ielp/Isfp experience," ICERI Proceedings, 2010, pp. 6285-6285.

[21] C Dörfer and M Vázquez, "The internationalization of higher education-local tendencies and realities in the education of students of engineering and natural sciences in a mexican a university-a case study," in Proc. INTED Conference, 2012, pp. 1766-1772

[22] A. İ Gümüşeli, M. Zagudillin, and Ö. Hacıfazlıŏglu, "Implementation of change at the local level: Motivations for internationalization of higher education among university lecturers," Eğitim ve Bilim Dergisi, 2012.

[23] X. Yan and C. Lin, Reflection on the development strategies of internationalization for local institutions of higher learning in the context of globalization-Taking Wenzhou University as example," Journal of Wenzhou University (Natural Sciences), vol. 2, no. 10, 2009.

[24] J. Knight, "The importance of local and international engagement in building a "successful" university," presented at the Eurasian Higher Education Leaders' Forums, June 2014.

[25] Y. Zhang, Y. Wang, and H. Tian, "Study on evaluation index factors of local university international trade major undergraduates' innovative ability," Value Engineering, vol. 20, p. 154, 2013.

Lipeng Feng was born in June 1981 in Shanxi, China. She got the Ph.D (logistics engineering), 2012, School of Logistics, Southwest Jiaotong University, Chengdu, China; the master of social science (quantitative economy), 2006 ,School of Economy and Management, North China University of Technology, Beijing, China; the bachelor of social science (logistics management), 2002, the Department of Business Administration, Beijing Wuzi University, Beijing, China.

She is associate professor in School of Economics Management, Chongqing University of Arts and Sciences. Now she is visiting scholar in SMART Infrastructure Facility, University of Wollongong, Australia. Now her research interest is e-commerce supply chain. Dr. Feng is a member of the Chongqing Logistics Society. 